\title{
ELECTRIC POWER, UNBALANCED GROWTH, AND THE DEVELOPMENT OF THE T.V.A. PCWER SERVICE AREA
}

\section{Virgil L. Christian, Jr., and Claude M. Vaughan*}

\section{INTRODUCTION}

The basic proposition advanced in this paper is that the electric fower component of the Tennessee Valley Authority has some of the characteristics of a leading industry in the sense described by proponents of unbalanced growth. Before advancing evidence to support this proposition, it might be well to review very briefly the doctrine of unbalanced growth.

\section{A. Unbalanced Growth Doctrine}

In his analysis of growth strategies, Hirschman assumes that an underdeveloped country (region) has a dearth of ability to make investment decisions. 1 It follows that regional growth will not be possible unless there is an investment strategy which creates imbalances leading to further investment decisions within the region. According to Streeten, "The pressures created by lack of balance may render factors of production and particularly entrepreneurial decisions more responsible to economic incentives." 2 Unbalanced growth therefore can be characterizec as "development by a chain of disequilibria."3 Such a strategy leads to (a) investment in social overhead capital and/or (b) investment in a specific industry which occupies a central position in regional output. Investment of the latter type is most successful when the chosen industry occupies an intermediate stage of production and is linked backward to industries which provide inputs to it and forward to industries which use its output as an input. The greater the interdependence the greater the potential for regional growth. In addition, if various industries in the production chain are subject to economies of scale ---especially the strategic industry!---and these economies are passed on in the form of lower input prices, then they reinforce linkage effects ir. stimulating growth.

\section{E. Unbalanced Growth in the Tennessee Valley}

The Tennessee Valley region, in comparisor with most other areas of the United States, was underdeveloped at the time the Authority was created. The assumption here is that this is too well known to require a dreary recital of the standard indicators of economic well-being to support it. Likewise, there is no intention to take sides in the balanced growth versus unbalanced growth controversy. Adherents of the balanced growth thesis lean heavily on limited markets to validate their arguments, and, as the entire United States was available to absorb regional output, expending industries were not entirely, or even primarily, dependent upon the simultaneous expansion of aggregate demand in the valley.4 Hence, one can argue that the electric power component of T.V.A.acted as a leading industry in the Tennessee Valley without being involved in the debate, simply because the issue is not joired. Finally, the social overhead aspects of investment in T.V.A. are largely ignored in this paper. This does not mean that they are unimportant, but it does mean that they are distinct from the issue under consideration.

The electric power industry in the Tennessee Valley fits the role of a strategically placed industry well: it certainly occupies a central position in regional output. It had forward linkage to industries in which electrict power is a principal component in the cost of production (aluminum, ferro-alloys, chemicals, radioactive materials), and backward linkage to the mining and transportation of coal.5 Finally, the decision to invest in the electric power industry resulted in investment in an industry which enjoys economies of scale, and those industries which were forwardly linked to it benefitted from pecuniary externalities. As they grew, in turn, the need for power expanded, and this led the power industry directly to an increase in the demand for variable inputs, principally coal, and ultimately to an increase in the demand for new and more efficient capital. The electric power

*Department of Economics, University of Kentucky. 
industry itself benefitted from pecuniary externalities attributable to economies of scale in the production and transportation of coal--more intensive use of capital in mining and the unit train in hauling. The cycle was then repeated: lower cost of inputs to power, lower price of power, increased use of power and increased demand for other inputs in industries in which power was a major element in costs. The entire configuration advanced, and is still advancing, in the meantime having brought about a broad advance in total regional output.

Nevertheless, the notion that one can prove that the lion's share of credit for regional growth in the T.V.A. region should go to the electric power industry is fraught with danger. "Post hoc, ergo propter hoc" is a lurking menace. The problem, of course, arises from the need to isolate the effects of the one industry from those of other significant economic variables of the period. Three points are worth mentioning in this connection. First, some other investment was taking place in the T.V.A..region at the same time, and it is possible that subsequent growth was due to it rather than to the power component of T.V.A. Second, there has been steady expansion of output nationwide during most of T.V.A.'s existence, and, as the Tennessee Valley economy was not closed, a measure of growth in regional output would be expected even in the absence of specific intra-regional factors Third, a shift in the regional trade balance toward increased export of commodities produced independently of electric power might have induced parallel growth, through linkage, in industries supplying them. There is little evidence that this happened on a major scale, but it must be admitted as a possibility in the absence of proof to the contrary.

The foregoing difficulties, along with others not mentioned, have led to a rather modest objective in this paper. No attempt is made to compare the rate of growth in the region with that of any other region or to estimate what the regional growth rate would have been in the absence of the electric power component of T.V.A. Instead, the purpose is to show that both the rate and kind of industrial growth in the power service area reflect T.V.A. 's sizeable investment in the generation, transmission, and distribution of electric power strongly enough to suggest that the power industry was a leading industry in the technical sense defined by proponents of unbalanced growth.

\section{T.V.A. ELECTRIC POWER AS A LEADING INDUSTRY}

The essential characteristic of a leading industry is that it be able to induce further investment. This it does in the main by creating a "Class of 'easy-to-exploit' investment opportunities," to steal Hirschman's phrase, which thrive on external economies passed on by the leading industry. The induced industries, often called satellites, use the leader's output as a principal input; there is a direct forward linkage. Should the leading industry be an important user of regionally produced inputs, it may induce investment in supplying industries--a backward linkage. Regional growth, as opposed to general growth,will be maximized if the linked industries find it desirable, or even necessary, to be in near proximity to the leader. Finally, if the inducing industry is large, or has the potential for becoming large without losing its ability to create and pass on external economies, it has an additional important advantage in fulfilling its role as leader.

\section{A. T.V.A. and External Economies}

It is the contention here that the electric power component of T.V.A. fits reasonably we11 the prescription above. There is little doubt that it has been a creator of external economies. Following Scitovsky, one may say that "pecuniary external economies" exist whenever the profit function of a firm is of the form

$$
P=G\left(x_{1}, 1_{1}, c_{1}, . . ., x_{2}, 1_{2}, c_{2}\right) .
$$

That is, whenever the profits of a given firm depend not only upon its own physica1 outputs and inputs, $x_{1}, 1_{1}, c_{1}, . ._{6}$. ,but a1so upon the outputs and inputs, $x_{2}, 1_{2}, c_{2}$, . . . for other firms. ${ }^{6}$ Hollis Chenery shows that the Scitovsky condition reduces, in nonmathematical terms, to the following state- 
ment: "With reference to particular industries, it can be said that industries $\mathrm{K}, \mathrm{L}, \mathrm{M}, . .$. , if investment in industries $\mathrm{A}, \mathrm{B}, \mathrm{C}, \ldots .$. , causes a decrease in the cost of supplying the demands for the products of $K, L, M$, . . " Thus, when T.V.A. expanded its capacity,increased its production, and lowered its rates per kwh to regional users,giving them a competitive advantage over firms outside and increasing their profits thereby, it created pecuniary external economies as defined above. ${ }^{\text {p }}$

Verification of pecuniary externalities enjoyed by heavy users of electric power can be found in studies by Kendrick and Hughs. According to Kendrick the rate of increase in productivity in the electric power industry has been the highest of any industry in the U.S.9 Recent studies indicate this trend has continued. According to Hughes, "The elasticity of total generating cost with respect to unit size (name plate capacity) has averaged .8 perhaps .9 for the large conventional units added in the 1960s."10

\section{B. Economics of Scale in the Electric Power Industry}

Economies of scale are inherent in the technology of the electric power industry and are exhibited in three phases of it: production and conversion of other sources of energy into electrical energy; transmission, moving large blocks of power at very high voltages; distribution, dissemination of power at stepped down voltages to the final consumer.

In generation, plant size affects costs in two ways. First, larger stations are able to produce the higher temperatures and pressures needed to rotate huge generators which maximize output per unit of fuel consumed.11 Second, larger plants utilize greater quantities of fuel, and gain quantity discounts and lower transportation costs thereby. A recent development in the reduction of fuel costs is the establishment of massive mine to mouth termal plants such as the one at Paradise, Kentucky, in 1964; its 650,000 kw unit lowered generations costs of the total system from 1.776 to $1.698 \mathrm{mil} \mathrm{s}$ per kilowatt. 12

In transmission, reduced costs are related to the amount of capital needed to meet peak conditions. Large scale generation is feasible only if the system is large enough to offset peaks by moving large blocks of power at high voltages over considerable distances. This requires location of steam plants at proper intervals, and may involve a programing problem of no mean magnitude, ${ }^{1}$ but its solution will lead to a more efficient utilization of capital.

Distribution is the final stage in the marketing of power. It begins at the various substations located throughout a load center; the substations reduce the voltage to levels needed to disseminate power to the various industrial, commercial, and residential customers. Once the distribution system is installed, line and line maintenance costs are relatively fixed so that it is possible for the system to handle greatly increased consumption with but moderately increased investment. Leland olds, in his analysis of the electric power industry, asserts, "as average residential use rises above the 6,000 kilowatt-hour level, incremental cost will stabilize at a small fraction of a cent per kilowatt-hour over the cost of wholesale power supply after taking account of distribution system losses," and adds that when consumption per customer increases fivefold, distribution system investment need only double, and when it increases tenfold a tripling of investment is al1 that is required. 14

Three additional factors have contributed significantly to the economies of scale which are related to expanded capacity, increased output, and low rates per kwh. Although this paper seeks to point out the relationship between T.V.A. power and industrial development it would be a gross oversight to ignore the role residential demand and sale of power to federal agencies has played in aiding the T.V.A. to obtain the economies of scale which are present in the system.

\section{Residential Demand and Economies of Scale in the Power Industry Itse1f}

Actually, T.V.A. was favored from the outset by the construction of a large system which, due to its size, was able to generate and transmit power efficiently. Low rates resulted, and the residential market responded dra- 
matically, so that the Authority was able to justify a steady increase in its facilities. The T.V.A. power service area managed to sustain a growth rate of 10.1 percent in residential consumption with a 2.8 percent rate of increase in residential units: 15 the comparable figures for private power nationwide were 6.7 and 3.3. In 1950 the consumption per residential unit in the private power sector was 65 percent that of the T.V.A. service area, but by 1963 the gap had widened until T.V.A., consumption per residence was two and one half times that of private power. ${ }^{16}$ Such a response of the residential market at T.V.A. rates indicates that this component of the demand for electric power may well have been more elastic than is generally supposed; that is, the residential market was willing to absorb sharp increases per residential unit at T.V.A. rates. The significance of this for the present analysis is that expansion of residential sales provide a stimulus to increased investment in the T.V.A. system that was not a direct consequence of industrial use, but served to complement it nevertheless. Industrial users benefitted to the extent that economies of scale over and above those that would have been induced by industrial use alone resulted.

The data in Tables $I$ and II indicate clearly the growth in residential consumption.

TABLE I

RESIDENTIAL SALES - - T.V.A. POWER SERVICE AREA

\begin{tabular}{lcrc}
\hline Year & $\begin{array}{c}\text { KWH Consumed } \\
\text { (Millions) }\end{array}$ & $\begin{array}{c}\text { Consumption per } \\
\text { Residential Customer }\end{array}$ & $\begin{array}{c}\text { Rate per KWH } \\
\text { (Mills) }\end{array}$ \\
\hline 1950 & 2796 & 2922 & 1.48 \\
1951 & 3595 & 3507 & 1.38 \\
1952 & 4122 & 3824 & 1.35 \\
1953 & 4838 & 4233 & 1.30 \\
1954 & 5452 & 4589 & 1.26 \\
1955 & & & \\
1956 & 6339 & 5175 & 1.22 \\
1957 & 7256 & 5727 & 1.16 \\
1958 & 7752 & 5963 & 1.15 \\
1959 & 9502 & 7118 & 1.07 \\
1960 & 9501 & 7762 & .99 \\
1961 & 10631 & & .98 \\
1962 & 11631 & 8728 & .96 \\
1963 & 12491 & 9023 & .94 \\
& 14026 & 9456 & \\
\hline
\end{tabular}

a/ Expiration of the Memphis contract

SOURCE: Annual Reports of the Tennessee Valley Authority, $1950-1963$ 
TABLE II

MAJOR MARKETS FOR T.V.A. POWER

\begin{tabular}{|c|c|c|c|c|c|c|c|}
\hline \multirow{2}{*}{ Year } & \multicolumn{2}{|c|}{ Industrial Sales- } & \multicolumn{2}{|c|}{ Residential Sales } & \multicolumn{2}{|c|}{ Federal Agencies } & \multirow{2}{*}{$\frac{\text { Total Sales }}{\text { Billions of } \mathrm{KWH}}$} \\
\hline & $\begin{array}{l}\text { Billions } \\
\text { KWH }\end{array}$ & $\begin{array}{l}\text { Percent } \\
\text { of Total }\end{array}$ & $\begin{array}{l}\text { Billions } \\
\text { KWH }\end{array}$ & $\begin{array}{l}\text { Percent } \\
\text { of Total }\end{array}$ & $\begin{array}{l}\text { Billions } \\
\text { KWH }\end{array}$ & $\begin{array}{l}\text { Percent } \\
\text { of Total }\end{array}$ & \\
\hline 1964 & 21.8 & 31.8 & 15.1 & 22.0 & 25.4 & 37.1 & 68.5 \\
\hline 1963 & 19.0 & 29.8 & 14.0 & 21.9 & 25.2 & 39.4 & 63.8 \\
\hline 1962 & 17.0 & 28.1 & 12.5 & 20.7 & 25.9 & 43.0 & 60.3 \\
\hline 1961 & 15.6 & 25.9 & 11.6 & 14.3 & 28.2 & 46.9 & 60.1 \\
\hline 1960 & 15.8 & 26.6 & 10.9 & 18.3 & 28.3 & 47.7 & 59.3 \\
\hline 1959 & 14.6 & 25.5 & 9.5 & 16.6 & 28.0 & 49.0 & 57.2 \\
\hline 1958 & 14.2 & 25.0 & 9.5 & 16.7 & 28.9 & 51.0 & 56.7 \\
\hline 1957 & 13.8 & 24.2 & 7.8 & 13.7 & 31.7 & 55.6 & 57.0 \\
\hline 1956 & 12.4 & 23.0 & 7.3 & 13.6 & 30.5 & 56.6 & 53.8 \\
\hline 1955 & 10.5 & 25.0 & 6.3 & 15.0 & 21.8 & 51.9 & 42.0 \\
\hline 1954 & 9.5 & 31.5 & 5.5 & 18.2 & 11.8 & 39.2 & 30.1 \\
\hline 1953 & 8.8 & 37.1 & 4.8 & 20.3 & 7.0 & 29.5 & 23.7 \\
\hline 1952 & 8.2 & 40.0 & 4.1 & 20.3 & 4.9 & 24.2 & 20.2 \\
\hline 1951 & 7.6 & 43.4 & 3.6 & 21.8 & 2.1 & 12.7 & 16.5 \\
\hline 1950 & 6.3 & 44.4 & 2.8 & 19.7 & 2.0 & 14.1 & 14.2 \\
\hline
\end{tabular}

a/ Industrial Sales includes direct and municipal cooperative

SOURCE: T.V.A. Annual Report, 1950-1964, pp. A36, A35, A40, A41, A37, 31, 45, 48, 35, 41, $37,34,36,28$. 
D. Sales to Federal Agencies and Economies of Scale

Another important factor which has contributed to the growth in sales of T.V.A. power has been the sale of electric power to federal agencies. With the opening of hostilities in Korea the Atomic Energy Commission called on the T.V.A. to supply huge blocks of power to its facilities at Oak Ridge and to its newly constructed plant at Paducah, Kentucky, and by 1955 federal agencies in the valley consumed more than half the total kwh sold by T.V.A. This upward trend continued through 1959. Since 1960 federal agencies have reduced their power requirements, and demand in the period 1960-1964 stabilized around 25 billion kwh--37.1 percent of total T.V.A. sales.

Consumption of huge blocks of power aids the utility in supplying low cost power. Not only are economies linked to the rated capacity of the plant, but to the characteristics of operation as we11. If the nature of the load is such as to permit prolonged generation with base load plants, huge economies are realized in generation. This is especially true if a large portion of daily peaks can be met with hydro generated power. The technical term for the ratio of average generation to installed capacity is load factor. In 1964 T.V.A. maintained a load factor of 75.2, and in the era since steam power has been an important component of T.V.A. power operations the load factor has averaged over 80 percent. ${ }^{18}$

TABLE III

LOAD FACTOR, T.V.A. STEAM POWER GENERATION

\begin{tabular}{ll}
\hline Year & Percent \\
\hline 1964 & 75.2 \\
1963 & 76.7 \\
1962 & 66.6 \\
1961 & 72.4 \\
1960 & 72.5 \\
1959 & 82.2 \\
1958 & 78.0 \\
1957 & 90.1 \\
1956 & 95.6 \\
1955 & 95.6 \\
1954 & 98.5 \\
1953 & 87.0 \\
1952 & 78.5 \\
\hline
\end{tabular}

a/ Ratio of average generation of all plants in system to installed capacity

SOURCE: T.V.A. Annual Reports, 1952-1964, pp. A21, A22, A23, A25, A32. 
E. Effect of Economies of Scale in the Electric Power Industry on Industrial Investment in the T.V.A. Region

The pattern in the T.V.A. region is clear: large initial investment, low rates, mass consumption, expanded capacity, economies of scale, lower rates, more consumption, more capacity, ad infinitum. With external economies, in Scitovsky terms, being created ai every turn of the screw. "Investment in an industry leads to an expansion of its capacity and may thus lower the prices of its products.. . The lowering of product prices benefits the users of these products . . . When these benefits accrue to firms, in the form of profits, they are called pecuniary external economies."19 Rates markedly lower than those found outside, offered a locational advantage to industries that are heavy users of electricity; it is natural to suppose that several firms in such industries migrated to the region. Whether this was actually the case is a matter of history, not conjecture, but if it was not the case the argument of this paper is patently untenable. On the other hand, if it was the case the argument is at least plausible, even though not proved in the sense of logical rigor.

\section{EMPIRICAL SUPPORT FOR THE LEADING INDUSTRY HYPOTHESIS}

Empirically, the thesis hinges upon the validity of the following propositions:

1. There has been a remarkable growth in the electric power component of T.V.A., and a continuing rate advantage to users there.

2. Paralleling the increase in the power component to T.V.A., there has been marked industrial growth in the region.

3. A significant proportion of the total industrial growth has taken place in industries that are heavy users of electric power, and who have therefore been net bereficiaries of external economies created by the electric power industry.

Before presenting data to support the above propositions, it may be well to make a brief aside in respect of two matters. First, the indirect effects of T.V.A.--those arising from its functions as social overhead capital --may be as important as the direct effects--linkages, forward and backward --on industries interdependent with electric power. However, indirect effects are difficult to trace empirically, and, more to the point, are a separate issue from the one under consideration here. Second, more emphasis has been placed on forward than on backward linkage for the simple reason that it appears to be important for electric power. 21 Nevertheless, it is a fact that the electric power industry, including T.V.A., has become a major purchaser of coal and indeed has absorbed some of the slack occasioned by the shift in railroads to liquid fuels. (See Table IV). The stimulus to the mining industry is not reflected in regional output figures, as most of the mines lie outside the Tennessee Valley itself, but there is a distinct benefit to the Appalachian area all the same.22

\section{A. Growth in the Electric Power Industry Itse1f}

The growth of the electric power component of T.V.A. has been quite phenomenal, as is shown by (a) investment in plant and equipment, and (b) in rated capacity of generation equipment. In 1950 investment in plant and equipment amounted to $\$ 544$ millions, 85 percent of which was in hydro installations; in $19 € 4$ the figure had risen more than fourfold to $\$ 2,103$ million, 70 percent in steam installations. 23 Growth in system capacity has followed investment in plant and equipment upward; it was $2,993610 \mathrm{kw}$ in 1964.24 Much of this increased capacity was in steam generation, which has climbed from $444,050 \mathrm{kw}$ in 1950 to $9,334,000 \mathrm{kw}$ in $1964-\overline{2} 5$ an average growth rate in steam generation nationwide was on 1 y 9.4 percent. ${ }^{25}$ As a result of 
TABLE IV

COAL CONSUMPTION BY THE ELECTRIC POWER INDUSTRY

1955-1964

(Millions of short tons)

\begin{tabular}{lccccc}
\hline Year & $\begin{array}{c}\text { U.S. } \\
\text { Production }\end{array}$ & $\begin{array}{c}\text { Electric Power } \\
\text { Consumption }\end{array}$ & $\begin{array}{c}\text { T.V.A. } \\
\text { Consumption }\end{array}$ & $\begin{array}{c}\text { Percent by } \\
\text { Electric Power }\end{array}$ & $\begin{array}{c}\text { Percent } \\
\text { by }\end{array}$ \\
\hline 1955 & 423 & 141 & 12.0 & 33.3 & 2.8 \\
1956 & 432 & 155 & 17.6 & 35.8 & 4.1 \\
1957 & 414 & 157 & 20.4 & 37.9 & 4.9 \\
1958 & 367 & 153 & 18.6 & 41.7 & 5.1 \\
1959 & 366 & 166 & 16.6 & 45.4 & 4.5 \\
1960 & 380 & 174 & 18.9 & 45.8 & 5.0 \\
1961 & 374 & 180 & 18.5 & 48.1 & 4.9 \\
1962 & 388 & 191 & 18.7 & 49.2 & 4.8 \\
1963 & 409 & 207 & 20.7 & 50.6 & 5.1 \\
1964 & 431 & 223 & 22.9 & 51.7 & 5.3 \\
\hline
\end{tabular}

SOURCE: Statistical Abstract of the United States, 1955-1964. Annual Reports of the Tennessee Valley Authority, 1955-1964. 
this investment in steam capacity T.V.A. nad amassed six plants with installed capacity of over one million kw by the end of 1964--one half the nation's total--and had two others with 720,000 kw capacity. Finally, total power generated by the system rose from 17.5 billion kwh in 1950 to 73.4 billion kwh in 1964, ${ }^{26}$ representing an imposing annual growth of 11.1 percent

As system capacity has gone up, rates have gone down, reflecting the economies of scale that seem to be present in the electric power industry. Consumption, for all categories of users, has risen apace. However, for residential consumers and for commercial and industrial users who buy from municipal or cooperative distributors the rise has been more due to increased use per customer than to an increased number of customers, since the average annual rates of increase were 17.9 percent and 3.1 percent respectively for residential users, and 7.6 percent and 1.7 percent for commercial and industrial users. The opposite was true for direct purchasers, the increase being attributable to additional customers. Data in Table V provide detailed evidence of the rate-consumption pattern for the period in question.

\section{B. Industrial Growth in the Tennessee Valley Region}

In 1933 employment in the T.V.A. power service area was predominantly agricultural; 62 percent of the labor force was employed on the farm. 27 For comparison, one can note that in the seven state Tennessee Valley area ${ }^{28} 55.5$ percent were engaged in agriculture, and for the United States as a whole only 29.9 percent. At the same time 12.1 percent of the labor force in the T.V.A. power service was engaged in manufacturing; percentages for the seven state area and the U. S. as a whole were 14.7 percent and 21.9 percent respectively. Ey 1964 the situation showed a dramatic reversal. Agricultural employment had fallen to 16.2 percent in the T.V.A. service area as compared with 13.4 percent in the seven states and 7.6 percent in the nation; manufacturing employment for the T.V.A. area had risen to 29.7 percent of the labor force, surpassing the 28.2 percent of the seven state area and 27.5 percent for the nation. In absolute terms, both the increase in the number of employees engaged in manufacturing and in their aggregate wages and salaries provide a vivid picture of progressive industrialization: the number rose from 220,000 in 1929 to 568,000 in 1964, and there was more than a tenfold jump, 1083 percent, from $\$ 213$ million to $\$ 2519$ million, in manufacturing salaries and wages--considerable even after allowing for price level changes. In fact, the jump in salaries and wages of manufacturing employees in the $\mathrm{T}$. V.A. area was nearly double that of the entire United States for the period in question, the latter figure being 549 percent.

\section{Growth in Industries that are Heavy Users of Electric Power}

The chemical and primary metals industries consume 63.4 percent of total industrial demand for electric power in the T.V.A. area. Significantly, for the period 1960 to 1965 investment in these two industries amounted to 951 million dollars out of total investment by all S.I.C. classified industries of 1,781 million--55.3 percent. The technology of these industries is such that electric power is a major input, and the new investment in them led to an increase in consumption of $985,735 \mathrm{kwh}$ out of a total increase by all S.I.C. industry of $1,647,842 \mathrm{kwh}, 29$ Moreover, they are high wage industries, at least relative to those found in the T.V.A. area, as the average per worker for chemical and allied industries was \$7,164 in 1965, and for primary metals it was $\$ 6,550$. Their importance to the regional economy is reflected by the number of employees, 85,000, out of a total of 557,000 for al1 S.I.C. industries, and by aggregate wages and salaries, \$146 million out of a total of $\$ 654$ million. A final point of interest emerges on the last line of Table V. It is that the 32 direct purchasers of electric power-satellites, if you will--consumed nearly 30 percent more power than all other commercial and industrial customers in 1964, and there were 178,881 of them! And the 32 paid an average of $.428 \mathrm{mills}$ per $\mathrm{kwh}$, as opposed to $.85 \mathrm{mills}$ for other commercial and industrial users of T.V.A. power, and 1.46 mills per kwh for similar users of Class A and B power. 30 The firms are sizeable, both in volume of employment and in aggregate payments of wages and salaries and presumable low rates for electric power were a consequential factor in their choice of location. 
TABLE $V$

SALES OF ELECTRIC POWER BY T.V.A.

$1950-1963$

(Millions of $\mathrm{KWH})$

\begin{tabular}{|c|c|c|c|c|c|c|c|}
\hline \multirow{2}{*}{ Year } & \multicolumn{2}{|c|}{ Residential } & \multicolumn{2}{|c|}{$\begin{array}{c}\text { Industrial } \\
\text { and Commercial }\end{array}$} & \multicolumn{2}{|c|}{ Direct Sales } & \multirow{2}{*}{$\begin{array}{l}\text { Number of } \\
\text { Customers }\end{array}$} \\
\hline & Rate - I/ & $\begin{array}{c}\text { KWH } \\
\text { Millions }\end{array}$ & Rate & $\begin{array}{l}\text { KWH } \\
\text { Millions }- \text { / }\end{array}$ & Rate & $\begin{array}{c}\text { KWH } \\
\text { Millions }\end{array}$ & \\
\hline 1950 & 1.48 & 2796 & 1.01 & 3737 & .320 & 3587 & 9 \\
\hline 1951 & 1.38 & 3595 & .96 & 4375 & .373 & 4452 & 9 \\
\hline 1952 & 1.35 & 4122 & .96 & 4714 & .528 & 4830 & 10 \\
\hline 1953 & 1.30 & 4838 & .96 & 5220 & .454 & 5109 & 15 \\
\hline 1954 & 1.26 & 5452 & .96 & 5530 & .427 & 5109 & 15 \\
\hline 1955 & 1.22 & 6339 & .95 & 6206 & .390 & 6031 & 16 \\
\hline 1956 & 1.16 & 7256 & .92 & 7091 & .385 & 7228 & 16 \\
\hline 1957 & 1.15 & 7752 & .90 & 7850 & .399 & 8007 & 17 \\
\hline 1958 & 1.07 & 9502 & .91 & 8050 & .421 & 8362 & 18 \\
\hline 1959 & 1.03 & 9501 c/ & .89 & 6976 & .430 & 9518 & 19 \\
\hline 1960 & .99 & 10936 & .88 & 7707 & .418 & 10364 & 25 \\
\hline 1961 & .98 & 11631 & .89 & 7886 & .432 & 10077 & 28 \\
\hline 1962 & .96 & 12491 & .89 & 8548 & .437 & 10951 & 32 \\
\hline 1963 & .94 & 14026 & .87 & 9501 & .428 & 12228 & 32 \\
\hline 1964 & .92 & 15064 & .85 & 10644 & .424 & 14077 & \\
\hline
\end{tabular}

a/ Rates are in mills per $\mathrm{KWH}$, and are system averages.

b/Through municipal and cooperative distributors

c/Expiration of Memphis contract

SOURCE: Annual Reports of the Tennessee Valley Authority, 1950-1963. 


\section{CONCLUSIONS}

In this paper an attempt has been made to shuw that unbalanced growth was a possibility for the T.V.A. area; that the electric power industry had the capability of being a leading industry because economies of scale are inherent in its technology and result in the creation of pecuniary external economies for industrial users of electric power; that the dramatic response of the residential market to low rates played a strong supporting role in leading to system expansion and still lower rates for industrial users; and that satelite industries who are enormous users of electric power, and who are important to the regional economy both in terms of the number they employ and the aggregate wages and salaries they pay, have been drawn to the area by tremendous rate differentials. Considerable evidence has been presented in support of the various propositions upon which the argument rests. The authors do not maintain that the set of hypotheses they have advanced is the only conceivable one that would not be contradicted by the facts, but it strikes them, at least, as being the most reasonable one. 


\section{FOOTNOTES}

$1_{\text {Albert }} 0$. Hirschman, The Strategy of Economic Development, Yale University Press, New Haven, T958, pp. $40 \mathrm{ff}$. Hirschman's point is that the lack of entrepreneurial skill with respect to investment decisions is the most critical shortage in underdeveloped economies. p. 107.

${ }^{2}$ Paul Streeten, Economics Integration, Leyden, A. W. Suthoff, 1961,

${ }^{3}$ Hirschman, op. cit.

${ }^{4}$ For a discussion of the theory of balanced growth and a review of the principal points at debate, see Robert B. Sutcliffe,"Balanced and Unbalanced Growth," Quarterly Journal of Economics, November 1964, pp. 621-640.

5 Other linkages, both inside and outside the region, can result. T.V.A.'s relationship with the A.E.C.could lead to future economies in power production. Likewise, industrial firms at Calvert City are not only power oriented but utilize each other's outputs as well.

6 Tibor Scitovsky, "Two Concepts of External Economies," Journal of Fo1itical Economy, LXII, April, 1954, p. 146.

${ }^{7}$ Hillis B. Chenery, "The Interdependence of Investment Decisions," in Abramovitz and others, The Allocation of Economic Resources, Stanford University Press, 1959 , p. 85 . descussion.

${ }^{8}$ Scitovsky,op. cit.,p.147.The T.V.A. case closely parallels Scitovsky's

${ }^{9}$ John W. Kendrick, Productivity.Trends in the United States, Princeton University Press, Princeton, New Jersey, 1961, pp. 136-137.

10 William R. Hughs, "Scale Frontiers in Electric Power," Technological Change in Regulated Industries, William M. Capron, Editor, Brookings Institute, Washington, D.C., 1971, p. 48.

${ }^{11}$ Steam generation accounted for 90.2 percent of conversion in 1963 . See Statistics of Electric Utilities in the United States, Privately Owned,1963, Washington, D.C., Federal Power Commission, 1965, p. 35.

12 T.V.A. Annual Report, 1964, p. 34.

${ }^{13}$ The problem is, of course, that of locating the steam plants within the region in such a way as to maximize cost reduction throughout the system given the geographical distribution of customer use.

${ }^{14}$ Leland 01ds, "The Economic Planning Function Under Public Regulation," American Economic Review, Vol. 48, No. 2 (May 1958), p. 533.

${ }^{15}$ Average household consumption jumped from $2922 \mathrm{kwh}$ in 1950 to $10230 \mathrm{kwh}$ in 1963. Then $10230=2922(1+r) 13, r=.101$.

${ }^{16}$ Annual Reports of the Tennessee Valley Authority, 1950-1963, and Statistics of Electric Utilities in the United States, Privately Owned, $\overline{1950}$ 1963 


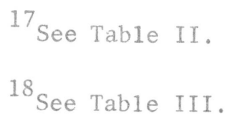

${ }^{19}$ Scitorsky, op. cit., p. 147. In this article Scitovsky points out that investment and the profits it creates through external economies are evidence of a disequilibrium condition, and that much of the conflict between writers on growth, who lay heavy emphasis on external economies, and general equilibrium theorists, who argue that they are trivial, can be resolved on this basis.

${ }^{20}$ Hirschman, op. cit., discusses the role of social overhead capital in economic development.

${ }^{21}$ Chenery and Watanabe, in their attempt to get at the matter quantitatively through the use of an input-output model, reach the same conclusion. Their data reflect an entirely different industrial configuration, of course than that found in the Tennessee Valley, but their computations with reference to the relative magnitude of forward and backward linkages for electric power seems relevant for that area also. H. Chenery and T. Watanabe, "International Comparisons of the Structure of Production," Econometrica, October 1958, pp. 487-521.

${ }^{22}$ For example, 17.9 percent of Kentucky's total coal production in 1964 went to T.V.A. Statistical Abstract, op. cit.

23 Annual Report of the Tennessee Valley Authority, 1950 and 1964.

${ }^{24}$ Tennessee Va11ey Authority Handbook, 1966, p. 184.

${ }^{25}$ Statistics Electric Utilities, op. cit., 1963, p. xx, Table 9.

${ }^{26}$ Annual Report, op. cit., 1950, p. A27, and 1964, p. A27.

${ }^{27}$ Tennessee Va1ley Authority Handbook, 1966, p. 107.

${ }^{28}$ Alabama, Georgia, Kentucky, Mississippi, North Carolina, Tennessee and Virginia.

29

Ibid.

${ }^{30}$ Annual Report, op. cit., 1963 and Statistics of Electrical Utilities, op. cit., 1963 . 